begin, and I have often been told that it does so early on the first Sunday of March, G.M.T.

What I said about the magpie beginning on the first Sunday (old style) was founded partly on report, but mainly on personal observation extending over some years at one breeding-place, where I have often seen them at work for the first time on this particular morning, and on one occasion in another locality on the same day.

This instinct is not confined to any particular tribe or order, but is common, I think, to all wild fowl, and the two instances given by Dr. Rae (vol. xxx. p. 7) of the regularity with which certain birds pass north to their breeding-grounds is precisely the point at issue, as I believe they begin work as soon as they arrive.

Scientific accuracy has not yet been directed to the subject, but there can be no doubt that from some cause, possibly a sharper and better defined division of summer and winter in former ages, all the feathered tribe have inherited an instinct in nest-building and in the time of their arrival at and departure from their breeding-grounds which guides them to a day in many cases without reference to the state of the weather.

WM. BROWN

I I2, West Regent Street, Glasgow, May 5

Watts's "Inorganic Chemistry"

THE review of my "Inorganic Chemistry" in NATURE of May I (p. 3) appears to have been written without much knowledge of the previous history of the work. The reviewer, indeed, writes as if he were criticising an entirely new book, whereas a glance at the preface might have shown him that the volume in question is the first part of the thirteenth edition of Fownes's well-known "Manual of Chemistry," the first edition of which was published in 1844

151, King Henry's Road, N.W.

\section{The Recent Earthquake}

I Notice that Mr. Topley, at the conclusion of his communication to you respecting the recent earthquake in Essex, remarks, "but at present we know of no observations in the central parts of Kent, Surrey, or Sussex." I wish therefore to mention, that although I did not myself notice anything in connection therewith, yet an invalid neighbour of mine, lying in bed, distinctly heard a rumbling noise about $9 \mathrm{~h} .20 \mathrm{~m}$. , and a moment afterwards perceived some pot plants in front of his window sway to and fro. This is the only incident with which I have been made acquainted.

The Observatory, Crowborough, Sussex, May 3

THE rise in the Essex waters detailed in my letter of last week still continues. Mr. Radforde Sharpe has kindly sent me the following additional heights that the water rises from Messrs. Courtauld and Co.'s well, at Bocking, Braintree, in inches above the surface of the ground:-

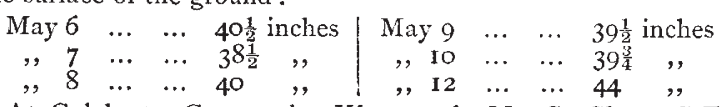

At Colchester Corporation Waterworks Mr. C. Clegg, C.E., reports the rise recorded is still maintained.

Museum, Jermyn Street, S. W.

\section{E. De Rance}

W. H. FRANCE.-Any good entomological text-book will give you the information you ask for.

\section{NOTES ON EARTHWORMS}

FVER since our great naturalist called attention to the common earthworm, we watch them with entirely different eyes as they creep timidly out on to the lawn or hurry across the gravel walk; as they collect the dead leaves or bits of string and cloth we may have dropped the evening before, or heap up their household refuse outside the entrance to their home.

He long ago pointed out its importance as a geological agent. The surface of the ground would be very different were it not that the earthworm is for ever at work bringing in the decaying vegetation and converting it into mould.
And, more than this, the superficial deposits are often modified to a considerable depth by the earthworms, which, carrying the earth moutbful by mouthful, and the gravel stone by stone, invert the order of stratification.

But we must not push this explanation of the origin of the universal surface mould too far. I received one caution from Darwin himself, many years ago when I was talking to him about the manner in which the chalk with which the land was dressed in Kent worked down. He told me to be careful to bear in mind the action of the great Kentish plough as it year by year turned swathe after swathe down the slopes. The result of this plough-down is clearly aistinguishable from wormmould. In his work on earthworms also he refers to another mould-forming agent of more universal operation and hardly less important cumulative effect. My attention was first directed to it by a lecture I heard delivered by Stoppani in Milan many years ago, in which he was explaining the action of the wind in modifying the surface of the earth, and especially in carrying dust, organic and inorganic. Richthofen and Drew have thus explained the origin of the loam that covers half Asia; and $\mathrm{Mr}$. Clement Reid has recently extended the same kind of observation to Great Britain (Geol. Mag., April i 384). Without this addition we can hardly explain how earth. worms could find the material for the manufacture of the mould which often fills the interstices of the ruins of a buried city.

We find, commonly, isolated tumps of moss-covered soil, and every gradation from that up to the large patches of mould which hang like little gardens on each sheltered ledge, where the greater part of the material must evidently have been carried from elsewhere and not have been brought up from below ; where it is obvious, from the character of the rocks, that the principal part of the mould cannot have been derived so much from them as from the wind-carried fragments of organic and inorganic material and the decomposition of the vegetation that soon began to grow upon it.

But we find also that the earthworms soon appear in such places, and set to work to mix up and modify all this various stuff that has by various agencies been brought together.

As squirrels, burying acorns and nuts in the autumn, have planted many an oak forest and hazel grove, so it is probable that the earthworms plant many of the ash and sycamore trees that we see perched in out-of-the-way corners, where it is difficult to explain how the blown seed can have got covered by mould enough to allow it to germinate. If an overhanging tree drops the seed, or the wind carries it anywhere near the worm's feedingground, it is dragged in and planted in leaf mould, and kept moist till spring time. At this time of the year we see clusters of sycamore seedlings growing up together out of the little worm-hills into which they had been dragged heavy end first.

It is therefore interesting to inquire into the various reasons that should make earthworms travel and occupy new ground. Round the margin of an overcrowded colony we should expect them to spread. They cannot live under water, so they have to move away before a flood. It has been stated that "they may live when completely submerged in water for nearly four months" (Romanes reviewing Darwin, NATURE, vol. xxiv. p. 553). But they nere killed off by a flood of a couple of days' duration in the Backs of the Colleges at Cambridge in August 1879. Some of them seem to have got on to the paths, which are raised above the surrounding meadows, and there died. Where the greatest number were found dead the ground had been submerged for a longer time. The following carefully recorded observations by the Rev. Henry Russell, of St. John's College, are worth noting :-..

"On Sunday, August 3, 1879, our paddock (the inclosed space in which the men play at lawn tennis, in front of the 
new court) was covered with water to the depth, at I p.m., when it was greatest, of four to five feet. The level of the paddock is much lower than that of the ground surrounding it. . . . Therefore, on Wednesday, August 6, I cut a trench from the north-west angle of the paddock across the raised path. . . . The water had drained off by Saturday evening, August 9. The rush of water from the west across the Fellows' garden had carried with it into the paddock a great quantity of worms, which, when the water had subsided, were observed, some very large, lying dead under the water. As the water drained off, these lay on the paddock and on the slopes of grass surrounding it, and the smell of them infected the air till Friday, August I 5."

Mr. Russell's observations go to show that the worms found dead were not all worms that had lived in the paddock, but those which had got washed out with the earth from the Fellows' gardens, and so they perhaps perished sooner being in the water. It is probable that worms buried deep in the earth under submerged meadows may, if they remain underground, hold out through much longer floods. However I gather that a large number perished in the adjoining parts of the Backs, and were seen on the paths and slopes as soon as the flood began to subside. Many of them were of exceptionally large size. I have heard of land injured by floods where the injury was supposed to be principally due to the destruction of all the earthworms. It is probable that the growth of peat-mosses may be in great part referred to the fact that the conditions were unfavourable to earthworms, for had they been there they would have worked up the vegetable matter into mould.

But there must be something besides floods that makes earthworms migrate.

If we drive a stick into the earth and move it about so as to shake the ground, the earthworms will come out to the surface and scuttle away in all directions. This was a common way of getting worms for fishing, and we used to be told, as Darwin notices, that the worms came out because they thought a mole was digging after them.

There must be however some other reason why worms will often come out to the surface in the daytime, and hurry away across a gravel path or on to a road, and why they then seem so much less sensitive to tremor of the ground about them than do the worms that come out to feed on the lawn.

From the analogy of other more highly organised animals I could not help thinking that there must be some creature that hunted the common earthworm, some worm ferret that drove them out. Many who have passed their lives in the country know well when they see a large field-mouse cantering down a road and showing little fear of man that a fiercer enemy than man is following the poor little animal with untiring certainty. If you draw aside and watch, you will soon see a weasel following by scent. Even a hare or rabbit will at length lie down paralysed with terror, and give itself up to the stoat that has followed it with deadly pertinacity. The sudden appearance of one or two strange birds in a neighbourhood has often been a source of wonderment, and it has sometimes been suggested in explanation that they had been chased by birds of prey and got up into strong currents of air. Those who have seen a peregrine drive a flight of rooks up into the sky can easily see how this might happen. In the cases to which I am referring the earthworm comes out like a hunted thing. I have also noticed that many of the worms that I found dead or torpid were maimed; generally they had their tail cut off, and this when there had been no digging in my garden for a long time, and although there are few birds that would touch them. I have frequently observed that the earthworms were apparently unwilling to go to ground again though $I$ have tried to make them in order to watch the rate and manner in which they buried themselves. A few days ago, however, I saw, I believe, the explanation of most of the cases I had been observing. A large earthworm about nine inches long, bright, clean, and healthylooking, was moving somewhat irregularly on the earth of a flower-bed. On stooping to examine it, I found a small yellow animal with a brown head holding on within about half an inch of the tail end of the worm. I sent it to Prof. Westwood, who writes: "Your worm-eating larva is evidently one of the Carabidæ, probably Steropus madidus" (see Gardener's Chronicle, 1854, p. 613). It was not disturbed by my taking up the worm, but went on biting its way round the worm, holding on like a bulldog, and bettering its hold every now and then. It had nearly got round the worm, leaving a lacerated ring. The wounded part seemed somewhat swollen, but on this point I am not clear, as the unequal power of extension of the wounded part may have produced the effect of swelling. Mr. Edwin Laurence has recorded (NATURE, vol. xxvi. p. 549) a similar circumstance observed by him in France, where, however, the larva seems to have attacked the worm differently, and with a view to killing it rather than cutting off a portion, and from his description, moreover, it would not appear to be the larva of the same species. He suggests that the numerous birds in England may have destroyed such an enemy of the earthworm. A sparrow would probably take the larva, and not touch the earthworm. One would have thought that the earthworm would have a better chance of rubbing off his deadly enemy in the earth than above ground, as a salmon is said to clean himself in a gravelly river, but we want further observations on this curious question, as well as on several others raised by the inquiry, How are worms transported to out-of-the-way places? and How long can they live in soils of various degrees of permeability when the surface is flooded?

\section{T. MCKENNY HuGHES}

\section{THE LOW BAROMETER OF JANUARY 26, I884}

I $N$ the end of January we gave a brief notice (see NATURE, vol. xxix. p. 316) of the unprecedentedly low barometric readings which were observed on the evening of January 26 in the middle districts of Scotland over which the centre of that great storm passed. The lowest reading, reduced to $32^{\circ}$ and sea-level, then given was 27.332 inches, and was observed by Mr. George Croucher at Ochtertyre, near Crieff. This still remains the lowest reading observed during the storm, and as it is absolutely the lowest known to have been observed in Europe, if not indeed the lowest on any land surface of the globe since the invention of the barometer, it is desirable to give an accurate record of it in NATURE.

On that occasion, Mr. Croucher's observations included the barometer, its attached thermometer, and a thermometer hung outside the window, it being too stormy to venture out. The observations near the time of greatest depression, corrected for instrumental errors and reduced to $32^{\circ}$ and sea-level, were, in inches, $27^{\circ} 631$ at 7 p.m., 27.527 at 7.45 p.m., 27.420 at 8.30 p.m., 27.390 at 9 p.m., 27.332 at 9.45 p.m., and 27.365 at 10.15 p.m. The correctness of these readings is amply attested by the hourly barometric readings made at a considerable number of the Scottish meteorological stations that evening.

At the meeting of the Royal Meteorological Society on February 20 , a paper was read on the storm of January 26 , in which it is remarked that "the lowest readings of the barometer (reduced to $32^{\circ}$ and sea-level) yet reported were 27.32 inches at Kilcreggan, and 27.332 inches at Ochtertyre." The obscrvations at Kilcreggan were made with an aneroid, whose crrors were unknown. From the hourly observations made at the different stations in Scotland, the isobars for each hour have been drawn, and, from a comparison of the Kilcreggan observations with these 